NBER WORKING PAPER SERIES

THE BEHAVIOR OF U.S. DEFICITS

Robert J. Barro

Working Paper No. 1309

INATCONAL BUREAU OF DCONOMIC RESEARCH

1050 Massachusetts Avenue

Cambridere, MA 02138

March 1984

Prepared for presentation at the NBER Conference on Business
Cycles, Puerto Rico, March 1994. This research is supported by the Cycles, Puerto Rico, March 1994. This research is sipported comments at the National Science Foundation. I have benefited from com February 1984, a ISPE Conference on Public Debt in Santa cruz, February 1984, seminar at UCLA, and the pre-conference for the NBER of the NBER's researoh program in researoh reported here is part of opinions expressed are those of the Economic Fluctuations. Any opinions expressed are those of the
author and not those of the National Bureau of Economic Research. 
NBER Working Paper \#1309

March 1984

The Behavior of U.S. Deficits

$\underline{A B S T R A C T}$

The tax-smoothing theory suggests that deficits would respond particularly to recession, temporarily high government spending, and anticipated inflation. My empirical estimates indicate that a relation of this type is reasonably stable in the U.S. since at least 1920. In particular, the statistical evidence does not support the idea that there has been a shift toward a fiscal policy that generates either more real public debt on average or that generates larger deficits in response to recessions. Further, the deficits for 1982-83 and projections for 1984 are consistent with the previous structure. The high values of these deficits reflect the customary response to substantial recession (interacting with big government) and to expected inflation.

Robert J. Barro

Department of Economics University of Chicago 1126 East $59 \mathrm{th}$ Street Chicago, IL 60637 
Much recent attention has focused on the large values of actual and projected federal deficits. In order to evaluate this discussion we have to know whether these deficits represent a shift in the structure of the government's fiscal policy, or just the usual reaction to other influences, such as recession, inflation and government spending. A related, but broader, question is whether the process that generates deficits in the post-World War II period differs systematically from that in place earlier-say, during the interwar period of 1920-40. For example, has there been a change in the average deficit or in the magnitude of the countercyclical response of deficits?

I begin by describing the tax-smoothing theory of deficits that I developed earlier. Then I estimate this model on U.S. data since 1920. Basically, the results are consistent with an unchanged structure of deficits since that time. Specifically, the recent deficits and the near-term projections of deficits reflect mainly the usual responses to recession and, it turns out, to anticipated inflation.

\section{The Tax-Smoothing Model of Deficits}

I analyze the determination of deficits within the framework of the tax-smoothing model that I developed in an earlier paper (Barro, 1979). ${ }^{1}$ In this approach the government faces the exogenous, deterministic stream of real expenditures, other than interest payments, as given by $g(t)$. The base of real taxable income is the deterministic amount $y(t)$, which 
generally depends on the path of tax rates. I think of $y(t)$ as a fixed fraction of the economy's real GNP for period $t$. Let $\tau(t)$ be the average tax rate at date $t$, so that the amount of real income-tax revenue is $\tau(t) y(t)$. Then, if the real interest rate is the constant $r$ and the initial real public debt is $b(0)$, the government's budget constraint in terms of present values. is ${ }^{2}$

$$
\int_{0}^{\infty} \tau(t) y(t) e^{-r t} d t=\int_{0 g}^{\infty} g(t) e^{-r t} d t+b(0) .
$$

In the present formulation I do not separate out the revenue from money creation from the government's other revenues. Rather, I think of inflationary finance as a tax on the holdings of money. Then, in order to focus on taxes in one period versus those in another, I combine the inflation tax with the variety of other levies (on income, sales, property, etc.) that apply at the same date. In particular, there seems to be no reason to give special treatment to the inflation tax. ${ }^{3}$

Suppose that the allocative effects from taxation depend on the "average marginal tax rate," $\tau^{m}(t)$, for each period. That is, the time path of average marginal tax rates, $\tau^{\mathbb{m}}(1), \tau^{\mathbb{m}}(2), \ldots$, influences people's incentives to work, produce and consume in the various periods. Here I take a Ramsey-like, optimal-taxation perspective in order to formulate a testable positive theory of the government's choices of tax rates over time. 4 In particular, if each period is similar in terms of elasticities of labor supply, etc., then the Ramsey formulation dictates roughly equal tax rates, $\tau^{m}(t)$, for each period. ${ }^{5}$ More generally, this approach would allow the tax rate to depend on time-varying features of the economy, such as war or peace, 
boom or recession, and so on. But, in order to bring out the main implications of the approach, I assume to begin with that the government plans for equal average marginal tax rates, $\tau^{m}(t)$, in each period. Then I examine later some perturbations from this path of uniform taxation. I assume that the average marginal tax rate for any period bears a stable relation to that period's average tax rate, $\tau(t)$--that is,

$$
\tau^{m}(t)=f[\tau(t)],
$$

where the function $f$ is invariant over time. In this case, the stabilization of average marginal tax rates entails stabilization of average tax rates. If $\tau$ denotes the constant value of the average tax rate, then the government's intertemporal budget constraint in equation (1) implies that this tax rate is

$$
\tau=\left[f^{\infty} g(t) e^{-r t} d t+b(0)\right] / \int_{0}^{\infty} y(t) e^{-r t} d t \text {. }
$$

Suppose that real government spending, $g(t)$, and the real tax base, $y(t)$, are fluctuating around trend values that grow at the common rate $n$. That is, the time paths, $g *(t)=g *(0) e^{n t}$ and $y *(t)=y *(0) e^{n t}$, have the same present values as the respective actual time paths, $g(t)$ and $y(t) .^{6}$ Then the current "normal" values, $g *(0)$ and $y *(0)$, satisfy the conditions,

$$
\begin{aligned}
& g *(0)=(r-n) \int_{0}^{\infty} g(t) e^{-r t} d t, \\
& y *(0)=(r-n) \int_{0}^{\infty} y(t) e^{-r t} d t
\end{aligned}
$$


Dropping the time subscripts and substituting back into equation (3) yields the formula for the (stabilized) average tax rate,

$$
\tau=\left[g^{*}+(r-n) b\right] / y^{*}
$$

Hence, the tax rate equals the ratio of normal real spending to normal real income, where normal real spending includes the real interest payments on the outstanding public debt, $x b$, less the amount financed by the usual growth of the real debt, nb. I discuss this last item further below. The current deficit--which I think of as the change in the real quantity of interest-bearing public debt, $\mathrm{db} / \mathrm{dt}$ - -is given at any date by

$$
\mathrm{db} / \mathrm{dt}=\mathrm{g}+\mathrm{rb}-\tau \mathrm{y}=\mathrm{g}+\mathrm{rb}-\mathrm{y}[\mathrm{g} *+(\mathrm{r}-\mathrm{n}) \mathrm{b}] / \mathrm{y}^{*} \cdot
$$

Aftex rearranging terms, this expression becomes

$$
a b / d t=\left(1-y / y^{*}\right)\left[g^{*}+(r-n) b\right]+g-g^{*}+n b
$$

The first term on the right side of equation (6) indicates that the real debt rises when output is below "normal"--that is, when $y / y *<1$. Effectively, tax revenues fall in proportion to the fall in output (in order for the average tax rate not to change). Hence, the amount of revenue lost is the proportional shortfall of output, $\left(1-y / y^{*}\right)$, multiplied by the normal amount of real government spending (and revenues), $g *+(r-n) b$. Note that, when tax rates are stablized over time, the coefficient of the cyclical variable, $\left(1-y / y^{*}\right)\left[g^{*}+(r-n) b\right]$, is unity in equation (6). Alternatively, if the 
government were to set relatively low tax rates during recessions, then it would have to engineer a more dramatic countercyclical response of deficits. In this case, the coefficient of the cyclical variable would be greater than one. In any case, the present analysis does not distinguish the automatic cyclical response of tax revenues under a given tax law (which people sometimes try to filter out in the construction of a "fullemployment deficit") from that effected through "discretionary" fiscal policy. For example, under a proportional income tax, average tax rates tend automatically to be stabilized over the business cycle, while under a graduated-rate setup, the average tax rate tends to be below normal during recessions and vice versa for booms. Thus, a well designed tax system may make it unnecessary to change the tax laws frequently in order to achieve the desired cyclical pattern of tax rates. If the analysis included adjustment costs for altering the tax laws, then it would be possible to study the optimal design of these laws. But, for the present analysis, I assume that some combination of automatic response within the tax system plus discretionary changes in the laws achieves the desired behavior of deficits.

The second term on the right side of equation (6), $g-g^{*}$, indicates that the real debt rises by the amount of temporarily high real government spending. Thereby, the government avoids abnormally high tax rates during periods when its expenditures are unusually high. Empirically, my measure of temporary spending focuses on the unusually high levels of military spending during wartime. Thus, the unitary coefficient on the $(g-g *)$ variable in lequation (6) reflects the government's desire to equalize tax rates during wartime and peacetime periods. Alternatively, if tax rates were above normal during wars, then the coefficient on the $\left(g-g^{*}\right)$ variable would be less than one. 
Finally, other things equal, the last term in equation (6) says that the real debt grows at the rate $n$, which is the trend growth rate of the economy. If the debt did not grow along with the economy, then interest payments would fall over time relative to GNP, which would be inconsistent with stabilizing the average tax rate.

Note that the present formulation deals with the conventional concept of the funded real public debt, b . Sometimes people suggest adding the implicit debt that corresponds to the anticipated present value of social social security benefits or of other governmental obligations. In fact, the pertinent variable for the government's decisions on taxes is $g *$ (plus the amount, $(r-n) b$ ), which is the anticipated flow of normal real spending. Aside from differences in the degree of uncertainty attached to various categories of expenditures, it is clear that future social security benefits play no special role--rather, they enter the analysis in a manner analogous to future defense spending, etc. However, the debt could be redefined if desired to include either the present value of social security benefits or of other expenditures. This change in definition would not alter the central economic problem, which concerns the government's choice of tax rates at different dates. But, different concepts of deficits would surely behave in different manners.

Suppose, for example, that people expect a bulge in social security benefits to occur 5 years from now and to last for 10 years. On this count, current spending $g$ is below the normal flow $g^{*}$, which calls for a surplus $(\mathrm{db} / \mathrm{dt}<0)$ in equation $(6)$. That is, the government raises taxes currently in order to prepare for the eventual bulge in spending. However, if the debt included the present value of social security benefits, then the rise over time in this present value (as the bulge in spending approaches) would 
offset the surplus in the funded debt. That is, the broader concept of public debt--which included social security--would not tend to decline over time. But, no matter how one defines the debt, the important point is that the prediction for tax rates is identical. Namely, the expectation of a bulge in future spending calls for a rise in current tax rates. (Unfortunately, I have not yet isolated empirically this type of effect for prospective government spending, whether for social security or for other types of spending.)

Dividing through in equation (6) by the level of real debt, $b$, the results can be written in terms of the proportionate growth rate of the real debt:

$$
(1 / b) d b / d t=\left(1-y / y^{*}\right)(g * / b+r-n)+\left(g-g^{*}\right) / b+n
$$

Empirically, the term $r-n$ is small relative to $g * / b$. (That is, normal real spending $g^{*}$ is large relative to real interest payments, rb, less the growth term, $\mathrm{nb}$. ) Hence, I neglect the term, $r-n$, in the subsequent analysis. Then it is appropriate to measure $g^{\star}$ as the normal amount of real government expenditures exclusive of interest payments.

When the time paths $g(t)$ and $y(t)$ are uncertain, the values $g^{*}$ and $y *$ are also uncertain. I interpret these magnitudes in equation (7) as corresponding to anticipated present values of real government spending and GNP, assuming a known value of the real interest rate $r$. Possibly, some further results could be obtained by modeling explicitly the uncertainty for future government spending and private endowments. 7 
The main point is that new information about the long-run values of spending, $g^{*}$, and income, $y^{*}$, lead to corresponding changes in the average tax rate, $\tau$, as shown in equation (5). Thus, the tax rate adjusts for surprise changes in spending and income, but the sign or magnitude of the necessary adjustments cannot be predicted in advance. In other words, the tax rate follows a Martingale. However, some predictable changes in tax rates may appear if--as mentioned before--the tax rate depends on the state of the economy. For example, if tax rates were lower than normal during recessions, then predictable increases in tax rates would occur along with the (predictable) ends of recessions. Similarly, if tax rates were higher than normal during wars, then predictable declines in tax rates would show up at the (predictable) ends of wars. Thus, the Martingale property for tax rates is not central to the approach followed in this paper. 8

Another property of the theory is that it prescribes no target value for the level of public debt or for the ratio of debt to income. A higher initial value of debt is "undesirable" in the sense that it requires a higher tax rate at each date (equation (5)), which then entails a larger excess burden from taxation. But (with default ruled out), it is not worthwhile for the government systematicaliy to run surpluses in order to pay off the debt. ${ }^{9}$ Such a policy implies temporarily high tax rates, which violates the tax-smoothing criterion. Thus, given the right-side variables in equation (7), there is no independent effect on the growth rate of debt from the starting value of the debt-income ratio. (This conclusion would still follow even if the government varied the tax rate with the business cycle or with conditions of war and peace.) 
The above argument is consistent with the marked tendency of the ratio of public debt to GNP to fall during peacetime, non-recession years. (See Barro, 1984, Chapter 15, for the long-term evidence on this behavior from the U.S. and the U.K.) The variable $g *$ incorporates a country's propensity to experience infrequent but possibly large wars. Therefore, temporary spending, $g-g^{*}$, is negative rather than zero during the typical peacetime year. Hence, the debt-income ratio tends to fall during peacetime, and to rise sharply during the infrequent large wars.

If the price level follows a known path, then equation (7) describes the time path of the real debt. Hence, the nominal debt--denoted by B--grows at the rate of inflation, $\pi$, plus the amount shown on the right side of equation (7). That is (neglecting the term, $r-n$, in equation (7)),

$$
(1 / B) d B / d t=n+\pi+\left(1-y / y^{*}\right)(g * / b)+\left(g-g^{*}\right) / b \text {. }
$$

Note that the inflation rate, $\pi$, has a one-to-one effect on the growth rate of the nominal debt.

A one-time surprise jump in the price level would shift the real debt, b, by a discrete amount in the opposite direction. Then, except for the shift in $b$ on the right side of equation (8), there would be no alteration to the subsequent path of growth rates of the debt--in particular, there is no tendency to adjust the nominal debt in order to compensate for the unexpected inflation (and thereby to restore some target value of the real debt). It follows in equation (8) that the variable $\pi$ should be replaced by the expected rate of inflation, $\pi^{e}$. (In the presence of indexed public debt, the actual rate of Inflation would be appropriate.) 
The main point is that the planned growth rate of the real debt, $(1 / B)(d B / d t)-\pi^{e}$, depends on the real variables (other than $\pi$ ) that appear on the right side of equation (8). Hence, the government's deficit policy is specified in real terms, rather than being subject to some form of money illusion.

Given the expected real interest rate $r$, a higher value of anticipated inflation shows up as a higher nominal interest rate. Hence, the previous result says that the government finances the (expected) inflation part of its nominal interest payments by issuing new nominal debt, rather than by levying taxes. Although this interpretation is suggestive, it turns out that the results do not depend on a one-to-one relation between expected inflation and nominal interest rates. Any discrepancy here appears as a different value for the expected real interest rate. But a different level for the real interest rate does not affect the growth rate of the debt in equation (8) (assuming a given real growth rate, $n$, and neglecting the effect from the $r-n$ term in equation (7)). A permanently higher real interest rate induces a once-and-for-all adjustment of the tax rate (equation. (5)), but no response of the deficit. On the other hand, if the expected real interest were temporarily high or low, then the deficit would adjust accordingly. Thus far, I have not investigated this possibility empirically.

When the debt is long term there are also changes in the real market value from changes in long-term nominal interest rates. A one-time jump in the nominal interest rate shifts the current market value of the debt by a discrete amount in the opposite direction. For example, Butkiewicz (1983) shows that the market value of the debt $\left(B^{\mathrm{m}}\right)$ can be well approximated empirically from the par value $\left(B^{P}\right)$ by using the formula, 


$$
B^{m} \simeq B^{P}(1+h c) /(1+h R) \text {, }
$$

where $c$ is the average coupon rate on the outstanding bonds, $R$ is the overall market yield, and $\mathrm{h}$ is the average maturity of the bonds. For given values of $c$ and $h$, the effect of a change in market yield on the market value of debt is approximately

$$
d B^{m} / B^{m} \simeq-d R \cdot h /(1+h R)
$$

Equations (7) and ( 8 ) describe the paths of the market value of the real and nominal debt, respectively, subsequent to the initial discrete shift in market value at the moment of the one-time shift in yield. In particular, this discrete shift affects subsequent growth rates of the debt only through the change in $b$ on the right side of the equations (and by any change in expected inflation that accompanies the shift in the long-term nominal interest rate). As with a surprise change in the price level, there is no tendency to return to a normal real market value of the debt. But, in order to explain the overall movements in the market value of the debt, it is necessary to include an additional variable--such as that shown in equation (10)--in. order to measure the effect of surprise changes in interest rates. In practice, I assume that all changes in the yield on government bonds, $R$, are unanticipated.

When considering the public debt, most researchers deal with the par value, rather than the market value. (However, some reliable estimates of market value are now available for the post-World War II period, as discussed below.) A surprise jump in nominal interest rates has no immediate effect on the debt when measured at par value. But, as the old debt matures, the 
government effectively replaces it with new debt, which bears say a higher coupon. (I assume that all debt is issued at par.) Thus, if nothing else changes, the government would face a rising path of real interest payments-that is, current real payments would be low relative to the average of anticipated future real payments. As with any path of rising real expenditures, the government's policy of tax-smoothing requires a rise in the current tax rate, which means a smaller current deficit. In other words, a surprise increase in nominal interest rates leads to a gradual reduction over time in the real debt when measured at par value. In fact, if there are no further surprises in interest rates (and the debt has finite maturity), then the real par value gradually approaches the real market value, which fell in a discrete fashion at the moment of the one-time shift in interest rates. Using equation (9), the effect on the par value of the debt from a change in the average coupon rate is

$$
d B^{P} / B^{P} \simeq-d c \cdot h /(1+h c)
$$

Suppose that the retirement of old debt means that the coupon rate, c, approaches the market yield, $R$, gradually, with the speed of adjustment depending inversely on the average maturity, h--that is,

$$
\mathrm{dc} / \mathrm{dt}=(1 / \mathrm{h})(\mathrm{R}-\mathrm{c}) \text {. }
$$

Then, using equation (11), the effect on the par value of the debt is

$$
\left(1 / B^{p}\right) d B^{p} / d t \simeq-(R-c) /(1+h c) \text {. }
$$


I add the right-side variable (unsuccessfully) to some of the equations that I estimate below. (I have data on $R, c$ and $h$ only for the period since 1946.)

Setup of the Empirical Analysis

The equation that I estimate with annual U.S. data over sub-samples of the period 1920-82 takes the form,

$$
\log \left(B_{t} / B_{t-1}\right)=a_{0}+a_{1} \pi_{t}^{e}+a_{2} \text { YVAR }_{t}+a_{3} \text { GVAR }_{t}+a_{4} \text { RVAR }_{t}+u_{t}
$$

where $u_{t}$ is an error term with the usual properties and the other variables are as follows:

B: end-of-calendar year (par or market) value of the U.S. government's interest-bearing public debt, exclusive of holdings at federal agencies and trust funds or the Federal Reserve. Market-value figures are based on Seater (1981) and Butkiewicz (1983). $\pi_{t}^{e}$ : expected rate of inflation (for the $\mathrm{CPI}^{10}$ ), generated as a fore- . casting relation based on the following: two annual lags of inflation, $\pi_{t-1}$ and $\pi_{t-2}$; two annual lags of monetary growth (based on annual averages of $M 1), \mu_{t-1}$ and $\mu_{t-2}$; and the interest rate on $4-6$ month commercial paper at the end of the previous year, $\mathrm{RC}_{t-1} \cdot 11$ That is, the equation for inflation is

$$
\pi_{t}=b_{0}+b_{1}{ }_{t-1}+b_{2}{ }_{t-2}+b_{3} \mu_{t-1}+b_{4} \mu_{t-2}+b_{5} R C_{t-1}+\text { error term. }
$$

This equation for inflation is estimated jointly with the debt equation (13). 
The behavior of inflation in the post-World War II period differs markedly from that before the war. First, there is positive persistence in inflation rates from year to year, which is not true earlier; second, lagged monetary growth is a positive predictor of inflation, which also does not apply earlier; and third, the variance of the inflation rate-conditioned on information from the previous year--is much smaller now than before. Some experimentation indicated that the main break in the structure of the inflation equation occurred around the Korean War--possibly with the accords between the Fed and the Treasury, which relieved the Fed from strict stabilization of interest rates. In any event, I estimate separate coefficients of the inflation equation (14) for the period up to 1953 and for the recent period, 1954-82. (It turns out that, in order to maximize the overall value of the likelihood function, it would be slightly preferable to break the sample at $1955 / 56$. But I have retained the break at 1953/54, which has some rationale a priori.) Note that in equation (13) the hypothesized coefficient of the $\pi^{e}$ variable is $a_{1}=1$.

Returning to the specification of variables in equation (13),

$$
\begin{aligned}
\text { YVAR }_{t} & \equiv\left(1-y_{t} / y_{t}^{*}\right) \cdot\left(g_{t}^{*} / \bar{b}_{t}\right), \\
\text { GVAR }_{t} & \equiv\left(g_{t}-g_{t}^{*}\right) / \bar{b}_{t},
\end{aligned}
$$

where $\bar{b}_{t}$ is a geometric average of the year-end values, $B_{t}$ and $B_{t-1}$, divided by the GNP deflator for year $t \cdot 12$

I base the measure of temporary real federal spending, $g_{t}-g_{t}^{*}$, on the variable that I used previously (Barro, 1981b) to explain fluctuations in real GNP. In that approach I isolated mainly the temporary parts of military spending that accompanied wars. Shifts in the ratio of federal non-defense expenditures to GNP and shifts during peacetime in the ratio of military spending to GNP were treated as predominantly permanent (in the sense that 
the ratios followed random walks). Sahasakul (1983) finds additional components of temporary real federal spending from the following: 1) a drift since the 1930 s in the ratio of federal transfers to GNP, 2) the tendency since the 1930 s of real federal transfers to move countercyclically, and 3) the tendency of wars to crowd out the non-military components of federal spending. However, these influences do not introduce variables that are independent of those that I include anyway in the equation to explain the growth rate of debt. Main1y, there are implications for the interpretations of coefficients--for example, the variable GVAR will measure the impact of temporary wartime spending net of the typical transitory decline in the other components of real federal spending during wartime. Recall that the taxsmoothing model predicts that the coefficient of GVAR $_{t}$ in equation (13) is $a_{3}=1$. But the crowding-out of other federal spending during wars implies $a_{3}<1$. In addition, if tax rates are somewhat above normal during wartime, then the coefficient $a_{3}$ would be reduced further below one.

For the cyclical variable YVAR in equation (13), I need a measure of the temporary shortfall of output, $\left(1-y_{t} / y_{t}^{*}\right)$. In my previous study (Barro, 1979), I used the deviation of current real GNP, which measured $y_{t}$, from trend real GNP, which measured $y_{t}^{*} \cdot 13$ I again report results with this construct, although it deals incorrectly with permanent shifts to the level of output. In these cases the variable indicates a permanent departure of output from normal. The results improve if $I$ use instead the unemployment rate, $U_{t}$, to proxy for the shortfall in output, $\left(1-y_{t} / y_{t}^{*}\right)$. As long as the unemployment rate is stationary in levels, this variable will work satisfactorily even when there are permanent shifts to the level of output. 
My main results use the total unemployment rate (including the military in the labor force ${ }^{14}$ ). Then I assume a stable relation between percentage shortfalls in output and the departure of the unemployment rate from a fixed natural rate:

$$
\left(1-y_{t} / y_{t}^{*}\right)=\lambda\left(U_{t}-.054\right)
$$

I take the natural unemployment rate in this formulation to be $5.4 \%$, which is the median rate over the sample $1890-1982$. (The value $5.4 \%$ is also close to the median and mean over the period 1948-82). For the post-World War II period (for which data are available), I obtain similar results if I use instead the prime-age male unemployment rate, $U_{t}^{m}$. Some people argue that this variable is more stable over long periods than the overall unemployment rate. Note that in equation (15) the parameter $\lambda$ is an Okun's Law type coefficient, which is likely to lie between 2 and 3.

As a general statement it would be preferable to construct normal output, $y_{t}^{*}$, as an explicit time-series representation for "permanent income." (My. measure for $g_{t}-g_{t}^{*}$ does take this approach, although only for military spending.) But I have thus far been unsuccessful along these lines in the construction of the variable $y_{t}^{*}$.

The variable YVAR ${ }_{t}$ depends also on normal real federal spending, $g_{t}^{*}$. I use here Sahasakul's (1983) concept of normal real federal spending, which combines normal military spending (which entered above into the construction of the GVAR variable) with measures of normal real federal spending for transfers and non-defense purchases. In this context the results are relatively Insensitive to the precise measure of $g_{t}^{*}$, as long as the variable picks up the longer term movements in the size of the federal government. But, when 
making comparisons over long periods, it is important to recall that the growth rate of the debt in equation (13) depends on the YVAR variable, which equals the percentage shortfall in output, $\left(1-\mathrm{y}_{\mathrm{t}} / \mathrm{y}_{\mathrm{t}}^{*}\right)$, multiplied by the ratio, $g_{t}^{*} / \bar{b}_{t}$. For example, in 1982 this last variable is .83, while in 1933 it is .17. Hence--because of the high value of normal real federal spending in recent years--a one percentage point shortfall in output has 5 times as much effect on the growth rate of debt as it would have in 1933 (where the percentage shortfall in output was much larger). 15

The tax-smoothing model suggests that the coefficient of YVAR $t$ in equation (13) would be $a_{2}=1$. However, the countercyclical behavior of transfers and any tendency to lower tax rates during recessions lead to $a_{2}>1$. When the unemployment rate proxies for the shortfall in output (equation (15)), the estimated coefficient on YVAR $_{t}$ is also multiplied by the Okun's Law coefficient, $\lambda$.

The variable RVAR ${ }_{t}$ in equation (13) accounts for the effects of change in interest rates. With the debt measured at par value, the interest-rate variable (available since 1946) is $\operatorname{RVAR}_{t}=\left(\bar{R}_{t}-\bar{c}_{t}\right) /\left(1+\bar{h}_{t} \bar{c}_{t}\right)$, where $R$. is the yield, $h$ is average maturity, $c$ is the average coupon rate, and overbars signify averages over the year. When the debt is measured at market value (available accurately since 1941), the interest-rate variable is $\operatorname{RVAR}_{t}=\bar{h}_{t}\left(R_{t}-R_{t-1}\right) /\left(1+\bar{h}_{t} \bar{R}_{t}\right)$. In both cases the hypothesized coefficient in equation (13) is $a_{4}=-1$. 


\section{Empirical Results}

Table 1 shows joint, maximum-likelihood estimates for the debt equation (13) and the inflation equation (14). For the debt equations in this table, the RVAR variable is omitted and the YVAR variable is based on the overall unemployment rate. The first six sets of results refer to the sample, 1920-40, 48-82, which excludes the years assoclated with World War II. The inflation equations report separate coefficients for the two sub-periods, 1920-40, 48-53, and 1954-82. Also, the observations in the inflation equation for the first sub-period, $1920-40,48-53$, are weighted by .40 in order to correct for heteroscedasticlty (that is, for a higher error variance in the earlier sample).

For set 1 in Table 1 , the coefficients of the Inflation equation in the earlier sub-period are Insignificant except for negative effects of the lagged interest rate (coefficient of $-1.2, s_{. e}=0.2$ ) and of the second $1 a g$ of monetary growth $\left(-.29, s_{. e}=.09\right)$. The first effect probably reflects the tendency for (real) interest rates to be high during financial crises, which were also times of deflation. The second effect picks up the tendency for reversals in monetary growth under the earlier monetary regime. By contrast, for the later sub-period 1954-82, the coefficients of the first lags of inflation and monetary growth are each strongly positive (.81, s.e. = .18; and .67, s.e. $=.15$, respectively). Surprisingly, the coefficlent of the nominal interest rate is still negative $\left(-.37\right.$, s.e. $\left.^{\prime}=.14\right)$. The results for the inflation equation remain basically similar in the specifications discussed later.

Expected inflation, $\pi_{t}^{e}$, is calculated from the coefficients in the inflation equation. In set 1 of Table 1 , the coefficient of $\pi_{t}^{e}$ in the debt equation is constrained to equal one, while in set 2 this coefficient 


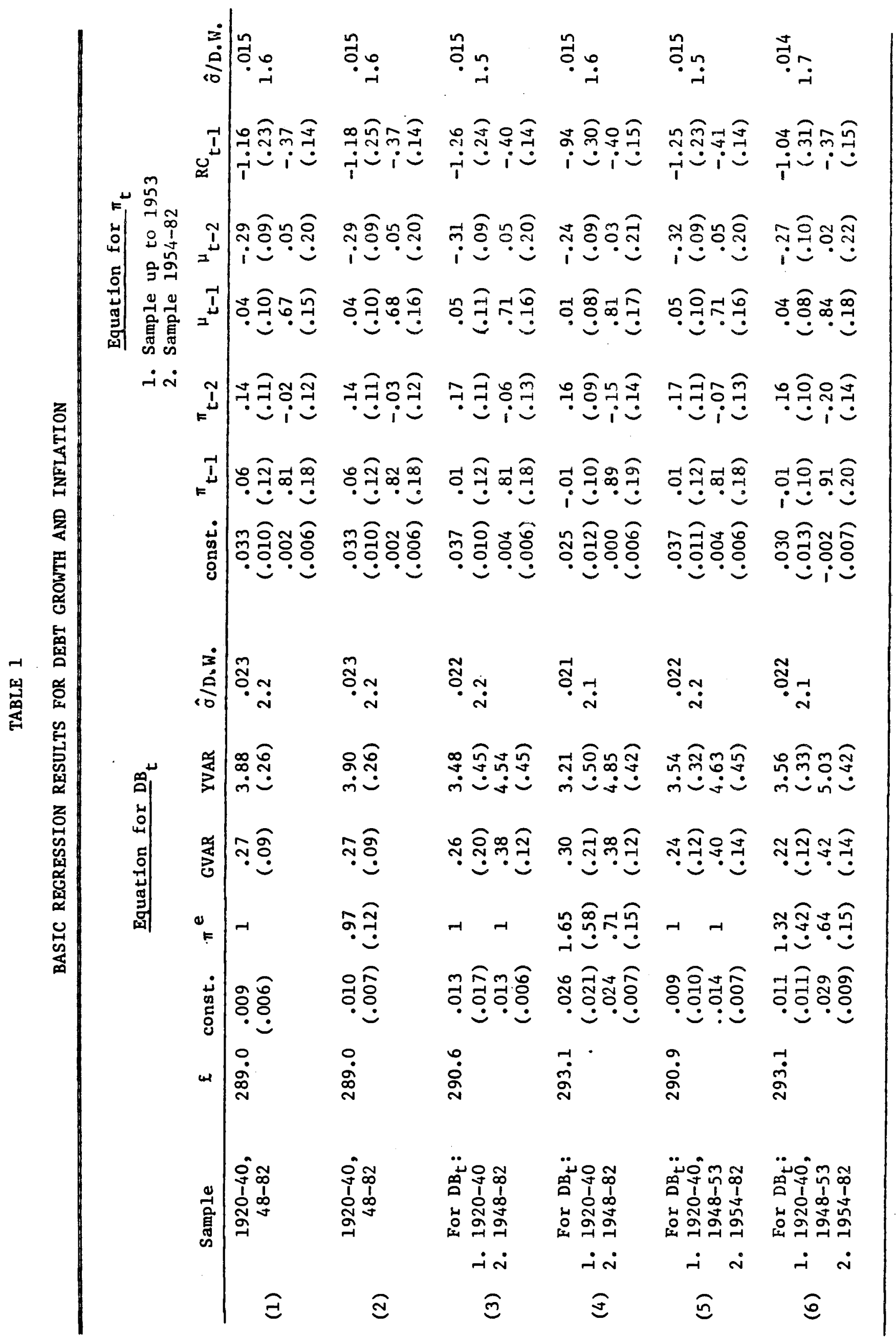




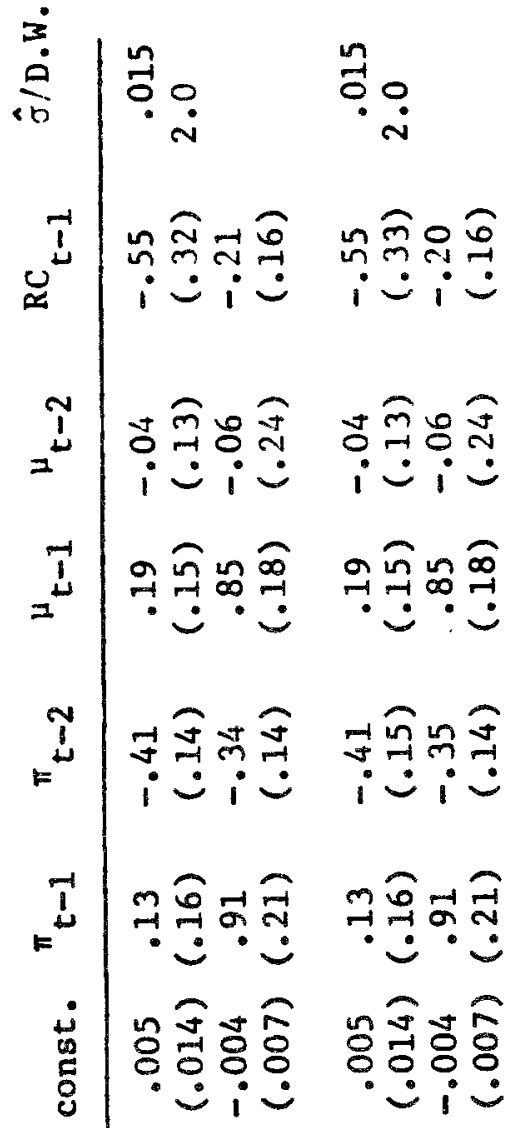

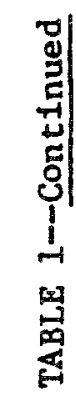

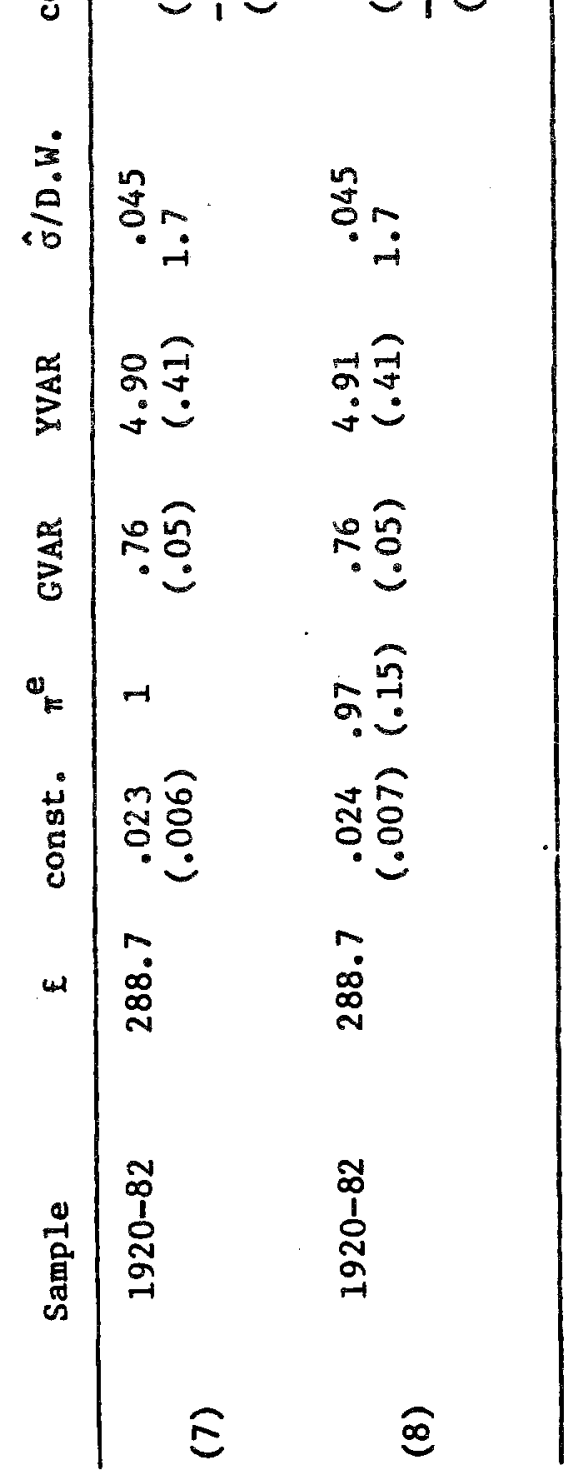


is left free. Note that the unconstrained estimate for this coefficient is .97, s.e. $=.12$, which is consistent with the theoretical value of unity. Therefore, I focus on the constrained results, which appear in set 1.

The estimated coefficient of $\operatorname{GVAR}(.27$, s.e. $=.09)$ is significant1y positive, but well below the value of unity that is suggested by the taxsmoothing model. The results in Sahasakul (1983) indicate that a small part of this discrepancy reflects the crowding-out of other components of federal spending during wartime. But the main element is the tendency for average tax rates to be above normal during wars. I discuss these results further when the observations for World War II are included.

The estimated coefficient of YVAR $(3.88$, s.e. $=.26)$ is positive and highly significant, which shows the strong countercyclical behavior of deficits. Dividing by an Okun's Law coefficient of 2-1/2 (see equation 15)) suggests that the reaction of debt growth to shortfalls in output involves a coefficient of about 1-1/2. The excess of this coefficient above one reflects the tendency during recessions for average tax rates to be below normal and for real federal transfers to be above normal (see Sahasakul, 1983, for a detailed breakdown between these two elements). To see the quantitative effect of unemployment on the deficit, recall that the pertinent variable is YVAR $_{t}=\left(U_{t}-.054\right) \cdot\left(g_{t}^{* / b_{t}}\right)$, which has an estimated coefficient of 3.9. In 1982 the variable $g_{t}^{*} / \bar{b}_{t}$ equals .83, which means that a one percentage point increase in the unemployment rate raises the estimated growth of the debt by $3.9 \cdot(0.83)=3.2$ percentage points per year. For a debt level of $\$ 850$ billion (December 1982), the corresponding increase in the deficit is by $3.2 \% \cdot 850=\$ 27$ billion. 
The standard-error-of-cstimate for the debt equation is $\hat{\sigma}=.023$ (that is, \pm 2.3 percentage points per year). This result corresponds to an $R^{2}$ of .91 , although the maximization of $R^{2}$ is not the criterion for the estimation. The Durbin-Watson Statistic of 2.2 suggests that serial correlation of residuals is not a problem.

The results in sets (3)-(6) of Table 1 check whether the debt equation is stable over various sub-periods. Sets 3 and 4 allow the coefficients for 1920-40 to differ from those for 1948-82. Sets 5 and 6 specify the first sub-period as 1920-40, 48-53, and the second as 1954-82. Also, sets 3 and 5 constrain the coefficient of the $\pi^{e}$ variable to unity, while sets 4 and 6 relax this constraint. In all cases the hypothesis of stable coefficients over the two sub-periods is accepted at conventional significance levels by likelihood-ratio tests, For example, for set 3 (where the samples are 1920-40 and 1948-82, and where the coefficient of $\pi^{e}$ is fixed at one), the value of $-2 \cdot \log$ (Iikelihood ratio) is 3.2 , which is below the $5 \%$ critical value for the $x^{2}$ distribution with 3 degrees of freedom of 7.8 . For set 4 (where the $\pi^{e}$ coefficients are unrestricted), the test statistic. is 8.2 , with a $5 \%$ critical value with 4 degrees of freedom of 9.5 . The results are basically similar in sets 5 and 6 , where the break in the sample is at $1953 / 54$.

These findings are important, since they indicate that the process for generating deficits in the interwar period, 1920-40 (or the period, 1920-40, 1948-53) is broadly similar to that in the post-World War II period, 1948-82 (or 1954-82). In particular, the statistical evidence does not support the idea that there has been a shift toward a fiscal policy that generates more real public debt on average or that generates larger deficits in response to recessions. (In set 3 of Table 1 , the estimated coefficients of the YVAR 
variable are 3.48 , s.e. $=.45$ for $1920-40$; and 4.54 , s.e. $=.45$ for $1948-82$. However, even this pattern of higher point estimates in the later period reverses later when I consider an alternative measure of the YVAR variable.)

Sets 7 and 8 of Table 1 deal with the full sample, 1920-82, which adds the years associated with World War II, 1941-47, to the previous sample. 16 Aside from the deterioration in fit--as measured by the standard-error-ofestimate, $\tilde{\sigma}-$ the most striking change is the increase in the coefficient of the GVAR variable. Naturaliy, this variable is the principal source of deficits during World War II. The estimated coefficient is now $.76, s_{.} e_{0}=.05$, which is highly significant and closer to the hypothesized value of unity. But it is also clear that the present formulation does not satisfactorily include the observations from World War II into the specification that works satisfactorily for the other years. One of the problems is that the estimated inflation eqaution (using the coefficients from the earlier sub-period, 1920-40, 1948-53see $n$. 16 above) generates implausibly low values of anticipated inflation during World War II. Specifically, these values are close to zero throughout the period 1941-45. The specification has to be changed to allow the . earlier monetary regime to generate high values of monetary growth and inflation during wartime. (similar problems arise when $I$ attempt to add the observations from World War I, 1917-19.) It is also clear that the measure of temporary wartime spending, GVAR, is subject to substantial measurement error during the major wars, which accounts for some of the increase in the standard-error-of-estimate. This problem can probably be handled by estimating the GVAR variable (as I did in Barro, 1981b) jointly with the debt and inflation equations.

Table 2 shows some additional results for the recent sample, 1954-82. Sets 9 and 10 (with the $\pi^{e}$ coefficient restricted to one and unrestricted, 


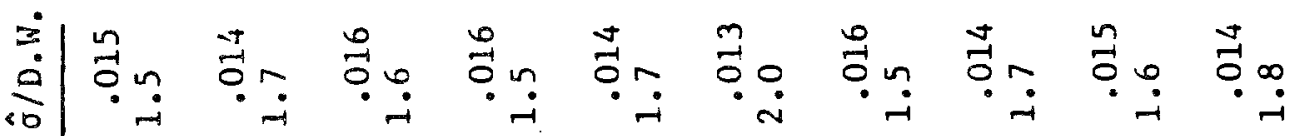

南 誌

* $\quad$ I

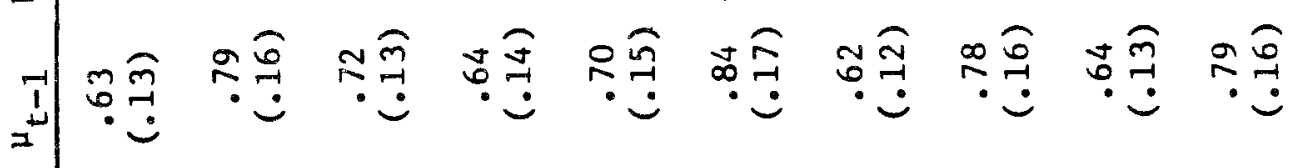

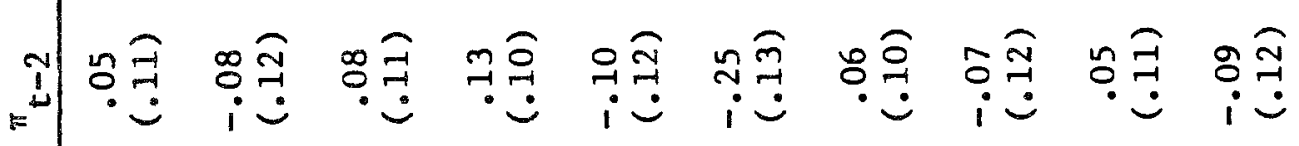

서

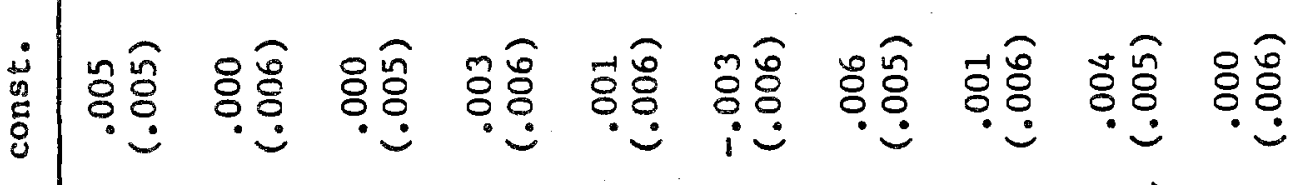

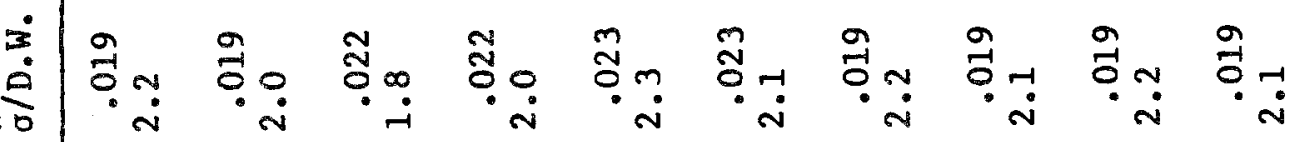
m鹪

궈

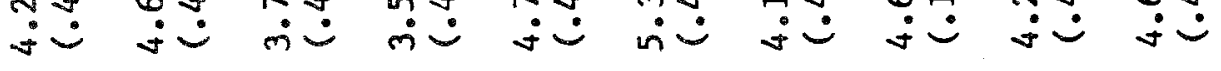

娄

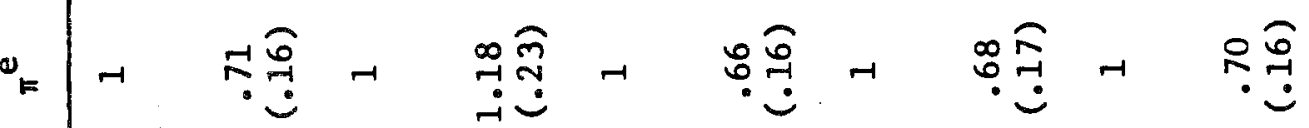

获

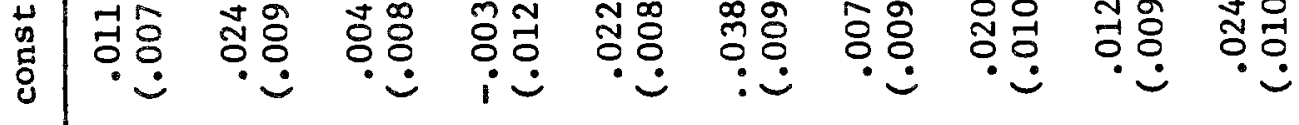

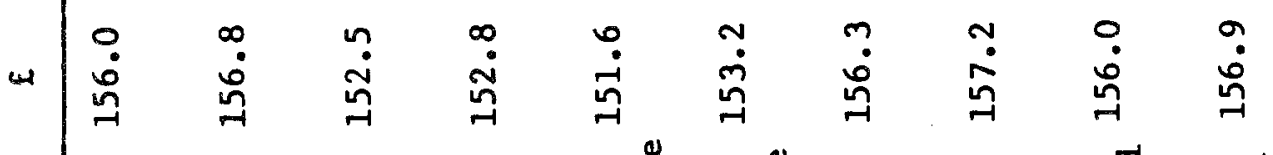

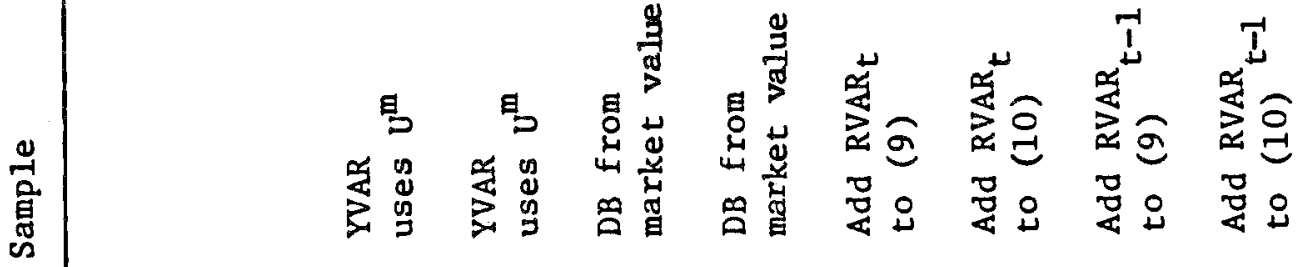

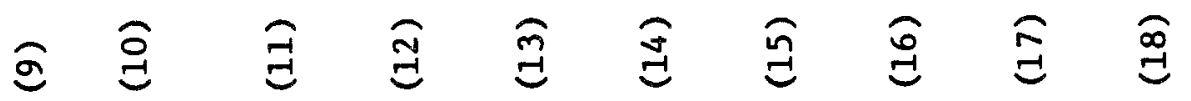


respectively) are similar to those for the longer sample (with World War II excluded), as shown in sets 1 and 2 of Table 1 . Sets 11 and 12 of Table 2 change the YVAR variable to use the prime-age male unemployment rate, $U_{t}^{m}-.041$, where .041 is the mean value of $U^{m}$ over the period 1954-82. Although the fit of the equation for debt growth in sets 11 and 12 is slightly worse than that in sets 9 and 10, the general nature of the results is similar. Sets 13 and 14 of Table 2 use the estimated market value of the public debt, rather than the par value, in the construction of the dependent variable. The equation for debt growth now includes an interest-rate variable, $\operatorname{RVAR}_{t}$, which picks up the effect on the market value of debt from changes in interest rates. For set 13 (where the coefficient of $\pi^{\mathrm{e}}$ is fixed at one), the estimated coefficient of $\operatorname{RVAR}_{t}$ is -.83 , s.e. $=.13$, which differs insignificantly from the hypothesized value of -1 . The other results are broadly similar to those found in sets 9 and 10, which are based on the par value of public debt.

In sets 15-18 of Table 2 I attempt to find an effect from changes in interest rates on the growth in debt when measured at par value. (The variable $\operatorname{RVAR}_{t}$ is now based on the difference between the yield and the coupon rate--see the notes to Table 2.) Although the hypothesized coefficient of RVAR $_{t}$ is -1 , the estimated values in sets 15 and 16 are positive, but with very high standard errors. Since the $\operatorname{RVAR}_{t}$ variable may be proxying for within-period revisions of expected inflation, I used instead the lagged value, RVAR $_{t-1}$, in sets 17 and 18 . The estimated coefficients do decrease-for example, to.- .13 , s.e. $=.60$, in set 17 . These results are consistent with the theoretical value of -1 , although the estimates are very imprecise. 
Table 3, which refers to the sample, 1920-40, 1948-82, uses output relative to trend rather than the unemployment rate in the construction of the cyclical variable, YVAR. The fits for the debt equation are substantially worse than those achieved with the unemployment rate--compare, for example, sets 19 and 20 in Table 3 with sets 1 and 2 in Table 1 . It turns out that the main differences arise in the post-World War II sample, especially during the 1974-76 recession. In any event the results based on output relâtive to trend are still consistent with an unchanged structure of the debt equation over either the sub-periods, 1920-40 and 1948-82 (sets 21 and 22 of Table 3 ) or 1920-40, 48-53 and 1954-82 (sets 23 and 24). One advantage of the results in Table 3 is that the estimated coefficient of the YVAR variable reveals directly the effect on debt growth from shortfalls in output. For example, in set 19, the estimated coefficient is $1.35, s_{.} e_{0}=.13$. This estimate is significantly above the value of unity that comes from the tax-smoothing model, although some of this excess reflects the countercyclical behavior of federal transfers. (Sets 21-24 show that the point estimates of the YVAR coefficients from the earlier sub-periods exceed those from the later sub-periods, which reverses the pattern found before with the unemployment rate. However, these differences across subperiods are statistically insignificant.)

\section{Some Episodes of U.S. Debt Issue}

Table 4 shows actual and estimated values for the growth rate of nominal debt, $D B_{t}$, and the inflation rate, $\pi_{t}$, over the sample 1920-40, 1948-82. The estimated values come from the regressions shown in set 1 of Table 1 (where the coefficient of $\pi^{e}$ is constrained to unity). Table 5 shows the 


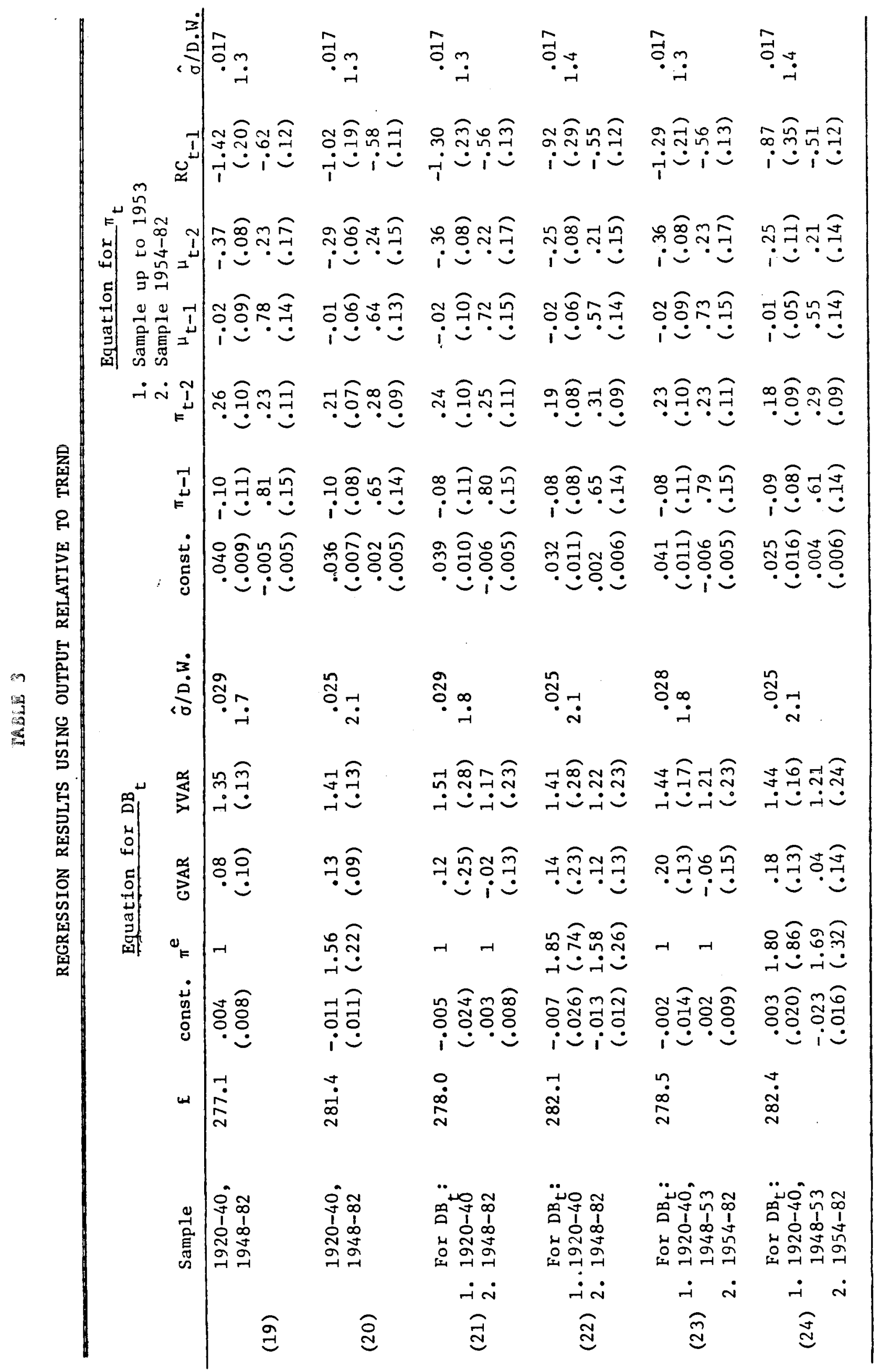


Notes to Tables 1-3

For the debt equation, the dependent variable, $\mathrm{DB}_{t}$, is the growth rate from end-December to end-December of the privately-held, interest-bearing public debt. The figures are par value except for sets 13-14, which use market values. For the inflation equation, the dependent variable, $\pi_{t}$, is the growth rate (January to January) of the CPI (measured without the shelter component since 1947).

The inflation equation (in sets 1-8 and 19-24) allows for separate coefficients for the sub-period up to 1953 and for the later sub-period, 1954-82. The earlier observations are weighted by .40 (the maximum likelihood estimate from set 1) to correct for heteroscedasticity. In sets $7-8$, which include World War II, the observations for $1943-47$ are deleted from the inflation equation.

For the debt equation, there are separate coefficients over two subperiods in the cases indicated (sets $3-6$ and 21-24). Otherwise, a single set of coefficients applies for the full sample. In any event, the variance of the error term is assumed to be constant for the full sample.

$E$ is the $\log$ of the value of the likelihood function. The independent variable $\pi^{e}$ is calculated as a forecast of $\pi_{t}$ from the coefficients of the inflation equation. The value 1 indicates that the coefficient of this variable is constrained to unity. The variable GVAR, based on temporary military spending, is discussed in the text.

The cyclical variable YVAR, described in the text, is based on the overall unemployment rate, $U_{t}-.054$, for sets $1-10$ and $13-18$. Sets 11 and 12 use the prime-age male unemployment rate, $U^{\mathrm{m}}-.041$. Sets $19-24$ use real GNP relative to trend.

In sets 13-14 of Table 2 (which use the market value of debt), the variable $\operatorname{RVAR}_{t}=\bar{h}_{t}\left(R_{t}-R_{t-1}\right) /\left(1+\hbar_{t} R_{t}\right)$, where $R$ is the average yield on government debt and $h$ is the average maturity. Overbars indicate estimates of averages over the year. For sets $15-16$ the variable is $\operatorname{RVAR}_{t}=\left(\bar{R}_{t}-\bar{c}_{t}\right) /\left(1+\bar{K}_{t} \bar{c}_{t}\right)$, where $c$ is the average coupon rate on government debt. Sets 17-18 use the lagged value of this last measure of RVAR.

$\hat{\sigma}$ is the standard-error-of-estimate. D.W. (shown below $\hat{\sigma}$ ) is the DurbinWatson statistic.

In the inflation equation, $\pi_{t-1}$ and $\pi_{t-2}$ are lagged values of the dependent variable, $\mu_{t-1}$ and $\mu_{t-2}$ are lagged values of monetary growth (based on annual averages of $\mathrm{MI}$ ), and $\mathrm{RC}_{\mathrm{t}-1}$ is the value from the previous December of the 4-6 month rate on commercial paper. 
Table 4

Values of Debt Crowth and Inflation

\begin{tabular}{|c|c|c|c|c|c|c|}
\hline & $\mathrm{DB}$ & $\hat{D B}$ & $\hat{D B}-\hat{D B}$ & $\pi$ & $\hat{\pi}$ & $\pi-\hat{\pi}$ \\
\hline $\begin{array}{l}1920 \\
1921 \\
1922 \\
1923 \\
1924\end{array}$ & $\begin{array}{l}-.038 \\
-.039 \\
-.036 \\
-.038 \\
-.049\end{array}$ & $\begin{array}{l}-.026 \\
-.030 \\
-.054 \\
-.045 \\
-.036\end{array}$ & $\begin{array}{r}-.012 \\
-.009 \\
.018 \\
.007 \\
-.014\end{array}$ & $\begin{array}{r}-.014 \\
-.117 \\
-.008 \\
.027 \\
.002\end{array}$ & $\begin{array}{l}-.021 \\
-.091 \\
-.062 \\
-.010 \\
-.028\end{array}$ & $\begin{array}{r}.007 \\
-.026 \\
.054 \\
.038 \\
.030\end{array}$ \\
\hline $\begin{array}{l}1925 \\
1926 \\
1927 \\
1928 \\
1929\end{array}$ & $\begin{array}{r}.000 \\
-.112 \\
-.064 \\
-.049 \\
-.059\end{array}$ & $\begin{array}{l}-.049 \\
-.073 \\
-.072 \\
-.048 \\
-.072\end{array}$ & $\begin{array}{r}.049 \\
-.039 \\
.008 \\
-.001 \\
.013\end{array}$ & $\begin{array}{r}.036 \\
-.023 \\
-.015 \\
-.010 \\
.000\end{array}$ & $\begin{array}{l}-.018 \\
-.022 \\
-.038 \\
-.023 \\
-.031\end{array}$ & $\begin{array}{l}.054 \\
.000 \\
.023 \\
.013 \\
.031\end{array}$ \\
\hline $\begin{array}{l}1930 \\
1931 \\
1932 \\
1933 \\
1934\end{array}$ & $\begin{array}{r}-.007 \\
.084 \\
.123 \\
.162 \\
.167\end{array}$ & $\begin{array}{l}.009 \\
.132 \\
.116 \\
.147 \\
.172\end{array}$ & $\begin{array}{r}-.016 \\
-.048 \\
.007 \\
.015 \\
-.005\end{array}$ & $\begin{array}{r}-.073 \\
-.106 \\
-.103 \\
.026 \\
.030\end{array}$ & $\begin{array}{l}-.030 \\
-.008 \\
-.021 \\
.010 \\
.040\end{array}$ & $\begin{array}{r}-.043 \\
-.098 \\
-.082 \\
.016 \\
-.011\end{array}$ \\
\hline $\begin{array}{l}1935 \\
1936 \\
1937 \\
1938 \\
1939\end{array}$ & $\begin{array}{l}.177 \\
.104 \\
.029 \\
.043 \\
.070\end{array}$ & $\begin{array}{l}.135 \\
.082 \\
.032 \\
.064 \\
.081\end{array}$ & $\begin{array}{r}.042 \\
.022 \\
-.002 \\
-.021 \\
-.011\end{array}$ & $\begin{array}{r}.015 \\
.019 \\
.009 \\
-.019 \\
-.002\end{array}$ & $\begin{array}{r}.036 \\
.016 \\
-.014 \\
-.011 \\
.015\end{array}$ & $\begin{array}{r}-.022 \\
.003 \\
.023 \\
-.008 \\
-.018\end{array}$ \\
\hline $\begin{array}{l}1940 \\
1948 \\
1949\end{array}$ & $\begin{array}{r}.072 \\
-.038 \\
.035\end{array}$ & $\begin{array}{r}.090 \\
-.018 \\
.006\end{array}$ & $\begin{array}{r}-.018 \\
-.019 \\
.029\end{array}$ & $\begin{array}{r}.012 \\
.008 \\
-.030\end{array}$ & $\begin{array}{r}.030 \\
-.008 \\
.002\end{array}$ & $\begin{array}{r}-.018 \\
.016 \\
-.032\end{array}$ \\
\hline $\begin{array}{l}1950 \\
1951 \\
1952 \\
1953 \\
1954\end{array}$ & $\begin{array}{r}-.014 \\
-.018 \\
.019 \\
.019 \\
.013\end{array}$ & $\begin{array}{r}.019 \\
.013 \\
.003 \\
-.022 \\
.027\end{array}$ & $\begin{array}{r}-.033 \\
-.031 \\
.016 \\
.041 \\
-.014\end{array}$ & $\begin{array}{r}.082 \\
.041 \\
.002 \\
.007 \\
-.012\end{array}$ & $\begin{array}{l}.015 \\
.017 \\
.014 \\
.001 \\
.018\end{array}$ & $\begin{array}{r}.067 \\
.023 \\
-.012 \\
.006 \\
-.031\end{array}$ \\
\hline $\begin{array}{l}1955 \\
1956 \\
1957 \\
1958 \\
1959\end{array}$ & $\begin{array}{r}.000 \\
-.029 \\
-.011 \\
.033 \\
.035\end{array}$ & $\begin{array}{r}-.019 \\
-.010 \\
.001 \\
.038 \\
.001\end{array}$ & $\begin{array}{r}.018 \\
-.019 \\
-.012 \\
-.005 \\
.034\end{array}$ & $\begin{array}{l}.000 \\
.033 \\
.034 \\
.013 \\
.011\end{array}$ & $\begin{array}{r}-.001 \\
.013 \\
.025 \\
.019 \\
.008\end{array}$ & $\begin{array}{r}.001 \\
.020 \\
.010 \\
-.006 \\
.004\end{array}$ \\
\hline $\begin{array}{l}1960 \\
1961 \\
1962 \\
1963 \\
1964\end{array}$ & $\begin{array}{r}-.014 \\
.022 \\
.018 \\
.006 \\
.008\end{array}$ & $\begin{array}{l}.011 \\
.022 \\
.002 \\
.014 \\
.004\end{array}$ & $\begin{array}{r}-.025 \\
.000 \\
.016 \\
-.009 \\
.004\end{array}$ & $\begin{array}{l}.016 \\
.007 \\
.014 \\
.015 \\
.010\end{array}$ & $\begin{array}{l}.018 \\
.005 \\
.009 \\
.018 \\
.020\end{array}$ & $\begin{array}{r}-.002 \\
.002 \\
.005 \\
-.003 \\
-.011\end{array}$ \\
\hline
\end{tabular}


Table 4, continued

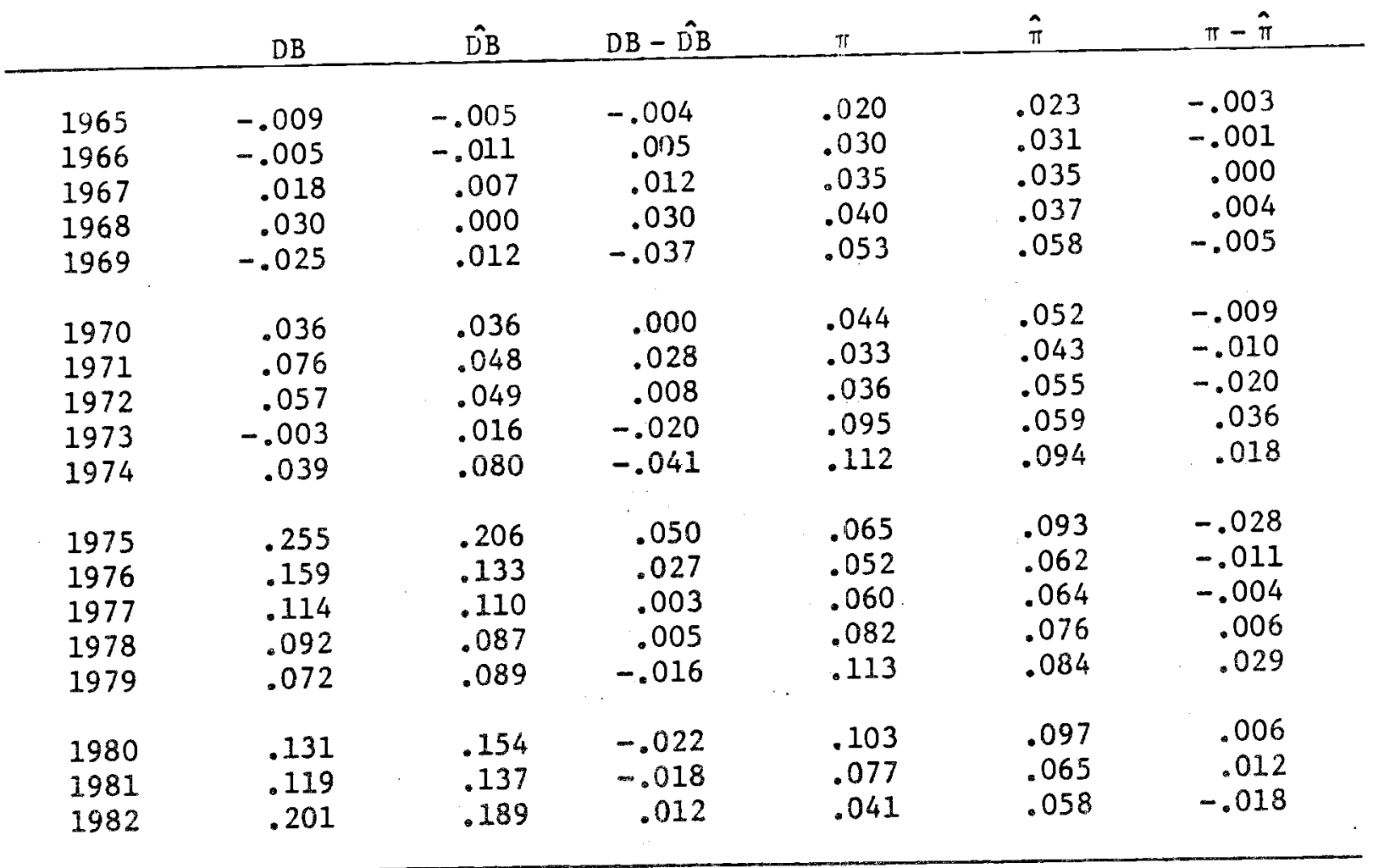

Notes: $D B_{t} \equiv \log \left(B_{t} / B_{t-1}\right)$, where $B_{t}$ is the value from the end of December of the privately-held part of the interest-bearing public debt--that is, the gross public debt less holdings by federal agencies and trust funds and the Federal Reserve and less anv noninterest-bearing debt. (See Barro, 1979, for details.) $\hat{D B}_{t}$ is the estimated value from set 1 of Table 1 .

$\pi_{t} \equiv \log \left(P_{t+1} / P_{t}\right)$, where $P_{t}$ is the January value of the seasonallyadjusted CPI (less shelter since 1947). $\hat{\pi}_{t}$ is the estimated value from set 1 of Table 1 . 
Table 5

Values of Explanatory Variables

\begin{tabular}{|c|c|c|c|}
\hline & GVAR & YVAR & $g * / b$ \\
\hline $\begin{array}{l}1917 \\
1918 \\
1919\end{array}$ & $\begin{array}{r}1.203 \\
1.067 \\
.284\end{array}$ & $\begin{array}{l}-.004 \\
-.036 \\
-.014\end{array}$ & $\begin{array}{r}1.12 \\
.89 \\
.37\end{array}$ \\
\hline $\begin{array}{l}1920 \\
1921 \\
1922 \\
1923 \\
1924\end{array}$ & $\begin{array}{r}-.072 \\
.015 \\
-.067 \\
-.071 \\
-.070\end{array}$ & $\begin{array}{r}.001 \\
.012 \\
.004 \\
-.006 \\
.000\end{array}$ & $\begin{array}{r}.31 \\
.16 \\
.20 \\
.24 \\
.22\end{array}$ \\
\hline $\begin{array}{l}1925 \\
1926 \\
1927 \\
1928 \\
1929\end{array}$ & $\begin{array}{l}-.083 \\
-.088 \\
-.089 \\
-.096 \\
-.101\end{array}$ & $\begin{array}{l}-.005 \\
-.009 \\
-.005 \\
-.002 \\
-.006\end{array}$ & $\begin{array}{l}.25 \\
.28 \\
.29 \\
.32 \\
.34\end{array}$ \\
\hline $\begin{array}{l}1930 \\
1931 \\
1932 \\
1933 \\
1934\end{array}$ & $\begin{array}{l}-.092 \\
-.069 \\
-.048 \\
-.045 \\
-.045\end{array}$ & $\begin{array}{l}.014 \\
.039 \\
.036 \\
.036 \\
.035\end{array}$ & $\begin{array}{r}.31 \\
.31 \\
.17 \\
.17 \\
.25\end{array}$ \\
\hline $\begin{array}{l}1935 \\
1936 \\
1937 \\
1938 \\
1939\end{array}$ & $\begin{array}{l}-.037 \\
-.034 \\
-.035 \\
-.029 \\
-.029\end{array}$ & $\begin{array}{l}.026 \\
.017 \\
.012 \\
.019 \\
.017\end{array}$ & $\begin{array}{l}.22 \\
.30 \\
.24 \\
.22 \\
.23\end{array}$ \\
\hline $\begin{array}{l}1940 \\
1941 \\
1942 \\
1943 \\
1944\end{array}$ & $\begin{array}{r}.008 \\
.147 \\
.476 \\
.571 \\
.494\end{array}$ & $\begin{array}{r}.013 \\
.003 \\
-.008 \\
-.010 \\
-.008\end{array}$ & $\begin{array}{l}.24 \\
.35 \\
.41 \\
.27 \\
.19\end{array}$ \\
\hline $\begin{array}{l}1945 \\
1946 \\
1947 \\
1948 \\
1949\end{array}$ & $\begin{array}{r}.345 \\
.039 \\
-.016 \\
-.022 \\
-.034\end{array}$ & $\begin{array}{r}-.005 \\
-.002 \\
-.003 \\
-.004 \\
.001\end{array}$ & $\begin{array}{l}.14 \\
.15 \\
.18 \\
.22 \\
.25\end{array}$ \\
\hline $\begin{array}{l}1950 \\
1951 \\
1952 \\
1953 \\
1954\end{array}$ & $\begin{array}{r}-.012 \\
.044 \\
.053 \\
.029 \\
.002\end{array}$ & $\begin{array}{r}-.001 \\
-.007 \\
-.009 \\
-.010 \\
.000\end{array}$ & $\begin{array}{r}.23 \\
.30 \\
.36 \\
.40 \\
.36\end{array}$ \\
\hline
\end{tabular}


Table 5, continued

\begin{tabular}{|c|c|c|c|}
\hline & GVAR & YVAR & $g^{* / / b}$ \\
\hline $\begin{array}{l}1955 \\
1956 \\
1957 \\
1958 \\
1959\end{array}$ & $\begin{array}{l}-.033 \\
-.036 \\
-.038 \\
-.041 \\
-.052\end{array}$ & $\begin{array}{r}-.005 \\
-.006 \\
-.006 \\
.005 \\
.000\end{array}$ & $\begin{array}{l}.39 \\
.41 \\
.46 \\
.47 \\
.48\end{array}$ \\
\hline $\begin{array}{l}1960 \\
1961 \\
1962 \\
1963 \\
1964\end{array}$ & $\begin{array}{l}-.054 \\
-.053 \\
-.053 \\
-.058 \\
-.062\end{array}$ & $\begin{array}{r}.000 \\
.006 \\
-.001 \\
.001 \\
-.002\end{array}$ & $\begin{array}{l}.49 \\
.52 \\
.57 \\
.57 \\
.59\end{array}$ \\
\hline $\begin{array}{l}1965 \\
1966 \\
1967 \\
1968 \\
1969\end{array}$ & $\begin{array}{r}-.051 \\
-.007 \\
.041 \\
.055 \\
.038\end{array}$ & $\begin{array}{l}-.006 \\
-.013 \\
-.013 \\
-.016 \\
-.017\end{array}$ & $\begin{array}{l}.62 \\
.70 \\
.74 \\
.78 \\
.85\end{array}$ \\
\hline $\begin{array}{l}1970 \\
1971 \\
1972 \\
1973 \\
1974\end{array}$ & $\begin{array}{l}-.018 \\
-.055 \\
-.061 \\
-.087 \\
-.087\end{array}$ & $\begin{array}{r}-.005 \\
.003 \\
.000 \\
-.007 \\
.000\end{array}$ & $\begin{array}{r}.91 \\
.94 \\
.98 \\
1.06 \\
1.16\end{array}$ \\
\hline $\begin{array}{l}1975 \\
1976 \\
1977 \\
1978 \\
1979\end{array}$ & $\begin{array}{r}-.076 \\
-.073 \\
-.067 \\
-.063 \\
-.060\end{array}$ & $\begin{array}{l}.032 \\
.021 \\
.014 \\
.005 \\
.003\end{array}$ & $\begin{array}{r}1.10 \\
.99 \\
.95 \\
.96 \\
.97\end{array}$ \\
\hline $\begin{array}{l}1980 \\
1981 \\
1982\end{array}$ & $\begin{array}{l}-.050 \\
-.049 \\
-.040\end{array}$ & $\begin{array}{l}.016 \\
.020 \\
.034\end{array}$ & $\begin{array}{l}.98 \\
.94 \\
.83\end{array}$ \\
\hline
\end{tabular}

Notes: $\operatorname{GVAR}_{t} \equiv\left(g_{t}-g_{t}^{*}\right) / \bar{b}_{t}$, where $\left(g_{t}-g_{t}^{*}\right)$ is temporary real defense spending (based on Barro, 1981b), and $\bar{b}_{t} \equiv \sqrt{\mathrm{B}_{t} \cdot \mathrm{B}_{t-1} / \mathrm{P}_{t}}$, where $B_{t}$ is the privately-held public debt at the end of year $t$ (Table 4) and $P_{t}$ is the GNP deflator for year $t$.

YVAR $_{t} \equiv\left(U_{t}-.054\right) \cdot g_{t}^{*} / \bar{b}_{t}$, where $U_{t}$ is the unemployment rate in the total labor force (adjusted as suggested by Darby (1976) for 1933-43) and $g_{t}^{*}$ is normal real federal spending, based on Sahasaku1 (1983). 
values of the explanatory variables, GVAR and YVAR (based on the overall unemployment rate), as well as the ratio, $g * / \bar{b}$, which enters into the construction of the YVAR variable.

Note first the negative values of $\mathrm{DB}$ and $\widehat{\mathrm{DB}}$ (i.e., "surpluses") throughout the 1920s. These derive first, from negative values of anticipated inflation, especially for 1921-22; second, from the economic boom (negative values of the cyclical variable, YVAR) for most of 1923-29; and third, from relatively low values of the GVAR variable. From 1931-40 the values of debt growth are all positive (i.e., "deficits"). This behavior reflects the countercyclical response of deficits to the Depression (that is, to the positive values of the cyclical variable, YVAR, particularly for 1931-35). There are large increases in real federal spending during the New Deal period after 1932, but not in the wartime spending that is the basis for my measure of temporary spending, GVAR. Therefore, higher federal spending is not a major element in my estimates of debt growth during the 1930s. (The variable GVAR equals $\left(g-g^{*}\right) / \bar{b}$, which is negative but declining in magnitude during the 1930 s because of the substantial rise in the real debt, $\bar{b}$.) However, the higher real spending on non-defense items--which I implicitly treat as permanent--would account for the large increases in tax rates that occurred under Hoover and Roosevelt from 1932-36. (See Barro and Sahasakul, 1983, for further discussion.) In any event, the actual debt growth, DB, is reasonably in line with the estimated values, $\widehat{\mathrm{DB}}$, throughout the $1930 \mathrm{~s}$. I have already mentioned that the dramatic increases in public debt during World War II derive primarily from the high values of temporary federal spending, as reflected in the GVAR variable. In fact, the average growth rate of the nominal debt from the end of 1940 until the end of 1945 is $34 \%$ per year. (From the end of 1916 until the end of 1919 it is over 100\% per year.) 
However, since my detailed results for the periods of the world wars are presently unsatisfactory, I cannot say much more about these episodes.

For the post-World War II period, note first that neither the actual nor estimated values of debt growth are very high during the Korean War, say 1951-53. The values of GVAR are high, but those for the cyclical variable, YVAR, are low. Also, the calculated values of expected inflation, $\pi^{e}$, are relatively low at this time. The response of deficits to recessions shows up, for example, in 1949, 1954, 1958 and 1961. The Kennedy-Johnson tax cuts for 1964-65 do not correspond to notable residuals in the equation for debt growth.

For the Vietnam War--say 1966-68--the positive residuals for debt. growth support the common view that taxes were raised insufficiently at this time. But, perhaps because of the surcharge on the income tax, a substantial negative residual does show up for 1969.

Since 1969, expected inflation has become an important influence on the deficit, as measured by the growth in the nominal debt. In particular, the values of $\pi^{e}$ (which have a one-to-one effect on the estimates of debt. growth, $\widehat{\mathrm{DB}}$ ) are between 4 and $6 \%$ for $1969-73$, increase to $9 \%$ for $1974-75$, fall to between 6 and $8 \%$ for 1976-79, reach 10\% in 1980, and then decline to $6 \%$ for $1981-82$.

The debt equation underpredicts the deficits during the recession years, 1975-76. (However, the error is much greater if the YVAR variable is based on real GNP relative to trend rather than the unemployment rate.) But the debt equation is basically on track for the 1980-82 recession. For 1982, the actual growth rate of the nominal debt is $20 \%$ (corresponding to an increase by $\$ 155$ billion in the nominal, privately-held, interest-bearing debt), while the estimated value is $19 \%$. This estimate breaks down into 
6 percentage points due to anticipated inflation $\left(\pi_{t}^{e}=6 \%\right.$, although $\pi_{t}=4 \%$ ) and 13 percentage points due to the recession (YVAR ${ }_{t}=.034$, based on the unemployment rate of $9.5 \%$. Because nothing special is going on with the constructed measure of temporary federal spending, GVAR, it turns out that the constant and the contribution from the GVAR variable essentially cancel out.

I also use the estimated equation to forecast deficits for 1983 and 1984. The inflation equation implies the value $\pi_{t}^{e}=4.8 \%$ for 1983 . (The actual value of the inflation rate for 1983 is around $3.5 \%$ ) The main element in the decline of inflationary expectations from 1982 to 1983 is the low actual rate of inflation, $\pi_{t}=4.1 \%$, for 1982 . Using the actual unemployment rate of $9.5 \%$ for 1983 , the resulting estimate for debt growth, $\widehat{D B}_{t}$, for 1983 is $16.6 \%$. Note that 4.8 percentage points of this total come from expected inflation, while 11.8 percentage points derive from the continuing effect of the recession. (The combined effect of the constant and the GVAR variable is near zero.) The projected value for debt growth implies that the level of debt would increase from $\$ 848$ billion at the end of December 1982 to $\$ 1,001$ billion at the end of December 1983. Thus, the predicted nominal deficit-in the sense of the change in the privately-held, interest-bearing public debt--for calendar 1983 is $\$ 153$ billion. (In order to get closer to conventional measures of the deficit, one should add the increase in high-powered money, which is roughly $\$ 15$ billion for calendar 1983.) The data that I have at this writing (kindly supplied to me by Eric Hanushek) Indicate that the actual value of privately-held public debt at the end of December 1983 is around $\$ 1,018$ billion. This figure implies an actual growth rate of the debt, $\mathrm{DB}_{t}$, of $18.3 \%$ for 1983 , as compared to 
my projected value of $16.6 \%$. The gap of .017 between actual and estimated values is not out of line with the fitted equation, for which the standarderror-of-estimate was $\hat{\sigma}=.023$. The actual deficit--in the sense of the change in the nominal, privately-held debt for calendar 1983 is about $\$ 170$ billion, as compared to my forecast of $\$ 153$ billion.

For 1984, the value of $\pi_{t}^{e}$ turns out to be $6.6 \%$. The main reason for the rise from 1983 (where $\pi_{t}^{e}=4.8 \%$ ) is the increase in the annual average rate of monetary growth from $6.3 \%$ in 1982 to $10.3 \%$ in 1983 . Assuming an unemployment rate of $7.8 \%$ for 1984 (see, for example, Litterman, 1984), the projected value of debt growth, $\widehat{\mathrm{DB}}_{t}$, for 1984 turns out to be $13.3 \%$ This forecast breaks up into 6.6 percentage points from expected inflation and 6.7 percentage points from the cyclical variable, YVAR ${ }_{t}$. The forecast implies that the level of debt would rise from about. $\$ 1,018$ billion at the end of 1983 to $\$ 1,163$ billion at the end of 1984 , or by $\$ 145$ billion during calendax 1984. (Again, one should add about $\$ 15$ billion for the creation of high-powered money to get closer to the standard concept of the nominal deficit.) This forecast seems to be roughly in line with other near-term projections of deficits. It also turns out that my forecasts for 1983-84 are basically similar if I use either the equation where the YVAR variable is based on output relative to trend (Table 3 , set 19), or the one based on the prime-age male unemployment rate (Table 2 , set 11 ).

The main point is that the actual behavior of public debt through 1983--as well as popular forecasts for 1984--are reasonably well in line with the experience of debt issue since at least the end of World War I. The main things that are out of line with the previous structure are projections of longer-term deficits on the order of $\$ 300$ billion, conditioned on relatively low values of the unemployment rate and expected inflation. Since there is 
nothing yet in the data to suggest this type of structural break, I view these forecasts of deficits as amounting to predictions that either taxes will be increased or spending decreased. Standard projections of deficits should not be regarded as forecasts, once the endogeneity of taxes and spending is taken into account.

For recent years, where the effects of the constant term and the GVAR variable turn out to cancel, the forecasts of debt growth--and hence deficitsemerge from a remarkably simple equation. Namely,

$$
\widehat{\mathrm{DB}}_{t}=\pi_{t}^{\mathrm{e}}+3.9 \cdot \mathrm{YVAR}_{\mathrm{t}}=\pi_{t}^{\mathrm{e}}+3.9 \cdot(\mathrm{U} t-.054) \cdot \mathrm{g}_{\mathrm{t}}^{\star} / \overline{\mathrm{b}}_{t}
$$

The values for $g_{t}^{* / b_{t}}$ until 1982 appear in Table 5, while the values for 1983 and 1984 are .75 and (roughly) .71, respectively. Using the value .71 in the expression above, the forecasting equation becomes

$$
\widehat{D B}_{t}=-.15+\pi_{t}^{e}+2.8 \cdot U_{t}
$$

Equation (16) provides a close approximation to the previously mentioned forecasts of debt growth for 1983-84. The equation would also apply satisfactorily to projections further out, subject to the absence of major changes in the ratio of normal federal spending to the debt, $g_{t}^{* / b} t$. (Recall that this ratio rose by a factor of 5 from 1933 to $1982 .{ }^{17}$ ) Notably, equation (16) implies that the planned growth rate of the real debt, $\hat{\mathrm{DB}}_{t}-\pi_{t}^{e}$, would approach zero if the unemployment rate were to decline to about $5-1 / 2 \%$. It implies further that the projected growth rate of the nominal debt, $\mathrm{DB}_{t}-{ }_{-}$ which determines the conventional nominal deficit (aside from changes in high-powered money)-would approach zero if, in addition, the expected rate 
of inflation were to approach zero. The point is that there is nothing in the experience of actual deficits through 1983 that conflicts in any major way with these projections. 


\section{REFERENCES}

Atkinson, A.B. and J.E. Stiglitz, Lectures on Public Economics, McGraw Hill, New York, 1980.

Barro, R.J., "On the Determination of the Public Debt," Journal of Political Economy, October 1979.

, "On the Predictability of Tax-Rate Changes," unpublished, October 1981a.

, "Output Effects of Government Purchases," Journal of Political Economy, December 1981b.

1981c. , Money, Expectations and Business Cycles, Academic Press, New York,

"Inflationary Finance under Discretion and Rules," Canadian Journal of Economics, January 1983.

, Macroeconomics, Wiley, New York, 1984.

Butkiewicz, J., "The Market Value of Outstanding Government Debt, Comment," Journal of Monetary Economics, May 1983.

Darby, M.R., "Three-and-a-half Million U.S. Employees Have Been Mislaid; or, an Explanation of Unemployment, 1934-1941," Journal of Political Economy, February 1976.

Kydland, F. and E. Prescott, "A Competitive Theory of Fluctuations and the Feasibility and Desirability of Stabilization Policy," in S. Fischer, ed., Rational Expectations and Economic Policy, University of Chicago Press for the National Bureau of Economic Research, 1980.

Litterman, R., "Economic Forecasts from a Vector Autoregression," Federal Reserve Bank of Minneapolis, January 1984.

Lucas, R. and N. Stokey, "Optimal Fiscal and Monetary Policy in an Economy without Capital," Journal of Monetary Economics, July 1983.

McCallum, B., "Bond-Financed Deficits and Inflation: A Ricardian Analysis," Journal of Political Economy, February 1984.

Pigou, A.C., A Study in Public Finance, Macmillan, London, 1928.

Ramsey, F.P., "A Contribution to the Theory of Taxation," Economic Journal, March 1927.

Sahasakul, C., "Are Marginal Tax-Rate Changes Predictable?" unpublished, University of Rochester, December 1983.

Seater, J., "The Market Value of Outstanding Government Debt, 1919-1975," Journal of Monetary Economics, July 1981. 
FOOTNOTES

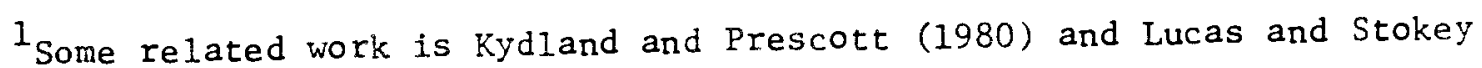
(1983). The general idea of the implications of tax-smoothing for the behavior of deficits appears also in Pigou (1928, Ch. VI).

2 This formulation assumes that the real interest rate exceeds the economy's steady-state growth rate. For a discussion, see McCallum (1984).

${ }^{3}$ Anticipated inflation amounts to a form of excise tax. But, unanticipated inflation entails a capital levy, which has different implications for the excess burden of taxation (see, for example, Barro 1983). However, changes in other kinds of taxes can also imply capital levies.

${ }^{4}$ For discussions of Ramsey taxation, see Atkinson and Stiglitz (1980, Chapter 12) and Ramsey (1927).

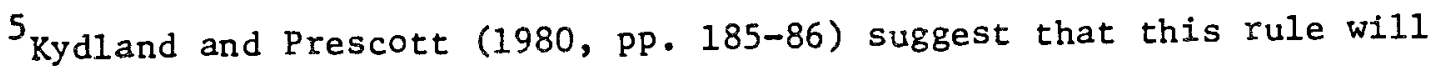
be close to optimal if intertemporal substitutions effects are strong.

-6 These assumptions rule out any drift in the ratio, $8 / y$. In the long run this drift would be subject to the bounds, $0<\mathrm{g} / \mathrm{y}<1$.

${ }^{7}$ See Lucas and Stokey (1983) for a treatment of uncertainty. 
${ }^{8}$ In a previous study (Barro, 1981a), I accepted the random-walk hypothesis for average tax rates, although the statistical tests were not very powerful. Subsequently, I have rejected the random-walk hypothesis for some revised systems. Sahasakul (1983) finds evidence that average marginal tax rates are lower than normal during recessions and higher than normal during wars.

${ }^{9}$ If an increase in the debt-income ratio raises the required real interest rate payable on public debt (perhaps because of an increasing probability of the government's default), then there would be a force that deters the government from amassing very high debt-income ratios.

${ }^{10}$ These inflation rates are January-to-January values, using the CPI less shelter since 1947. For 1943-47, the data are strongly affected by price controls. Instead of using the reported price levels, I substituted values based on the extrapolation of an estimated price-level equation from some previous research (Barro, 1981c, p. 157). This adjustment shifts the inflation rates as follows: from $2.9 \%$ to $25.8 \%$ for 1943 , from $2.3 \%$ to $13.0 \%$ for 1944 , from $2.2 \%$ to $3.2 \%$ for 1945 , from $16.7 \%$ to $-4.8 \%$ for 1946 , and from $10.2 \%$ to $-2.9 \%$ for 1947 . This procedure affects the subsequent results mainly for the samples that include the World War II years. (There are also some effects of lagged inflation rates on the estimates for 1948-49.)

11 Theoretically, the annual average of $\pi_{t}^{e}$ would matter, which means that some updating of expectations for current-period information comes into 
play. The present procedure excludes current-period information (and thereby avoids some econometric problems). I used the commercial paper rate, rather than say a 1-year Treasury Bill rate, in order to have a consistent variable for the full sample. The difference between a 4-6 month maturity and a 1-year maturity would not be of major significance for the results.

${ }^{12}$ The forms of the YVAR and GVAR variables in equation (13) arise as an approximation for discrete-time data to the continuous-time formulation in equation (8). The approximation seems to be satisfactory except for the very large values of $\left(g_{t}-g_{t}^{*}\right) / \bar{b}_{t}$ that arise at the start of World War $I$.

13 For trend real GNP, the growth rate was $3.4 \%$ per year since 1946 and before 1914. From 1915-45, the two trend lines were connected, implying an average growth rate of $2.5 \%$ per year.

${ }^{14}$ I also adjust the values from $1933-43$ as suggested by Darby (1976) to include New Deal workers as employed.

${ }^{15}$ The ratio of the real deficit to real GNP, $(\mathrm{db} / \mathrm{dt}) / \mathrm{y}_{\mathrm{t}}$, depends on $\mathrm{g}_{\mathrm{t}}^{*} / \mathrm{y}_{\mathrm{t}}$. This last variable is .21 in 1982 and .06 in 1933.

${ }^{16}$ Because of the problems with price controls (n. 10 above), I exclude the years 1943-47 from the inflation equation. The values of $\pi_{t}^{e}$ for these years are those implied by the estimated coefficients for the earlier subperiod, $1920-40,1948-53$. 
${ }^{17}$ If one plugs in the 1933 unemployment rate of $27 \%$ into equation (16), then (with $\pi_{t}^{e}=6 \%$ ) the projected growth rate of debt is a remarkable $67 \%$. The actual growth rate of debt for 1933 was only $16 \%$, which I attribute primarily to the smaller size of the federal government, as measured by the ratio, $g_{t}^{* / b} \vec{b}_{t}$. My assessment is that, if the U.S. encounters a much more serious recession than that in 1982, then (with no change in structure) we will observe numbers for deficits that dwarf those experienced recently. The main element that generates high real deficits is the interaction between recession (high unemployment) and big government. 